\title{
Profil Kejadian Fraktur Humerus pada Anak Di RSUP Dr. M. Djamil Padang
}

\author{
R.R. Dyana Wisnu Satiti', Roni Eka Sahputra ${ }^{2}$, Roza Silvia ${ }^{3}$ \\ ${ }^{1}$ Fakultas Kedokteran Universitas Andalas Padang \\ ${ }^{2}$ Bagian Bedah Fakultas Kedokteran Universitas Andalas Padang / RSUP Dr. M. Djamil Padang \\ ${ }^{3}$ Bagian Histologi Fakultas Kedokteran Universitas Andalas Padang
}

\begin{abstract}
A B S T R A C T
Latar Belakang. Fraktur sampai saat ini masih menjadi masalah utama dalam bidang kesehatan karena dapat mengenai semua kelompok usia, terutama anak-anak. Fraktur suprakondiler merupakan fraktur tersering yang ditemukan pada fraktur humerus anak dikarenakan faktor anatomi dan peristiwa trauma tunggal seperti kecelakaan lalu lintas dan terjatuh dari ketinggian.
\end{abstract}

Objektif. Penelitian ini bertujuan untuk mengetahui profil kejadian fraktur humerus pada anak yang dirawat di RSUP dr. M. Djamil Padang pada tahun 2014-2017.

Metode. Penelitian ini merupakan penelitian deskriptif dengan menggunakan data sekunder terhadap 43 pasien anak yang mengalami fraktur humerus dan telah menjalani terapi di Bagian Orthopedi RSUP dr. M. Djamil Padang pada tahun 20142017. Pengambilan sampel menggunakan teknik total sampling. Hasil penelitian didapatkan 43 kasus fraktur humerus pada anak antara tahun 2014-2017 di RSUP dr. M. Djamil Padang. Hasil. Terjadi peningkatan kasus pada tahun 2015 (37,2\%). Kelompok usia terbanyak adalah usia $12-17$ tahun $(48,9 \%)$ dan angka kejadian tertinggi dari semua kasus ditemukan pada anak laki-laki $(74,4 \%)$. Lokasi fraktur yang paling sering adalah pada distal humerus (69,3\%), lebih spesifik yaitu pada daerah suprakondiler humerus (46,5\%). Berdasarkan jenis fraktur didapatkan fraktur tertutup $(76,7 \%)$ lebih sering ditemukan dibanding fraktur terbuka (23,3\%). Tatalaksana yang sering digunakan yaitu dengan terapi operatif (76,7\%). Trauma tunggal (100\%) merupakan satu-satunya penyebab fraktur humerus pada anak dengan kecelakan lalu lintas $(67,4 \%)$ merupakan penyebab tersering terjadinya trauma tersebut.

Kesimpulan. Terdapat peningkatan fraktur humerus pada anak setiap tahunnya. Oleh sebab itu, perlunya pengawasan orang tua terhadap anak-anak agar dapat menurunkan angka kejadian fraktur humerus pada anak.

Kata kunci: Fraktur humerus, anak-anak, suprakondiler.

Background. Fractures are still a major problem in the health sector because they can affect all age groups, especially children. Supracondylar fracture is the most common fracture found in a child's humeral fracture due to anatomical factors and single trauma events such as traffic accidents and falls from a height.

Objective. This study aims to determine the incidence profile of humeral fractures in treated children at RSUP dr. M. Djamil Padang in 2014-2017.
Method. This study was a descriptive study using secondary data on 43 pediatric patients who had a humeral fracture and had undergone therapy in the Orthopedic Section of RSUP dr. M. Djamil Padang in 2014-2017. Sampling was done using the total sampling technique.

Result. The results showed that there are 43 cases of humeral fractures in children between 2014-2017 in RSUP Dr. M. Djamil Padang. There was an increasing number of cases in 2015 (37.2\%). The age group with the highest incidence number was $12-17$ years old (48.9\%) and boys were found to have the highest incidence among all of the cases (74.4\%). The most common fracture location is the distal humerus (69.3\%), more specifically in the supracondylar humeral region (46.5\%). Based on the type of fracture, closed fracture $(76.7 \%)$ is more common than open fracture (23.3\%). Management that is often used is operative therapy (76.7\%). Single trauma (100\%) is the only cause of humeral fracture in children with traffic accidents (67.4\%) as the most common cause of the trauma.

Conclusion. There has been an increasing fracture of the humerus in children annually. Because of that, the importance of parents to the children to reduce the rate of the humerus fracture on the child.

Keywords: Humeral Fracture, Children, Supracondylar

\section{Apa yang sudah diketahui tentang topik ini?}

Fraktur suprakondiler merupakan fraktur tersering yang ditemukan pada fraktur humerus anak dikarenakan faktor anatomi dan peristiwa trauma tunggal seperti kecelakaan lalu lintas dan terjatuh dari ketinggian.

\section{Apa yang ditambahkan pada studi ini?}

Terdapat peningkatan fraktur humerus pada anak setiap tahunnya. Oleh sebab itu, perlunya pengawasan orang tua terhadap anak-anak agar dapat menurunkan angka kejadian fraktur humerus pada anak.

\section{CORRESPONDING AUTHOR}

Name: R.R. Dyana Wisnu Satiti

Phone: +6282210099796

E-mail: rrdyanaws@gmail.com

ARTICLE INFORMATION

Received: September $23^{\text {rd }}$, 2020

Revised: October $15^{\text {th }}, 2020$

Available online: October $31^{\text {st }}, 2020$ 


\section{Pendahuluan}

Fraktur atau patahan pada kontinuitas struktur tulang, sampai saat ini masih menjadi suatu masalah utama dalam bidang kesehatan. ${ }^{1}$ Hal ini dikarenakan manifestasi yang ditimbulkan oleh fraktur berupa gangguan fungsi muskuloskeletal ataupun gangguan neurovaskular yang dapat mengakibatkan komplikasi berupa kecacatan bahkan sampai kematian apabila tidak ditatalaksana secara optimal. ${ }^{1,2}$ Salah satu komplikasi yang sangat berbahaya adalah sindroma kompartemen yang dapat mengakibatkan nekrosis saraf dan otot. Selain itu juga terdapat komplikasi umum berupa syok, koagulopati difus dan gangguan fungsi pernapasan yang terjadi 24 jam pertama setelah cedera yang dapat mengakibatkan kematian. ${ }^{1}$

Fraktur dapat mengenai semua kelompok usia, termasuk anak-anak. Pada kelompok anak-anak terjadi peningkatan kasus fraktur yang disebabkan oleh meningkatnya partisipasi dalam olahraga. Setidaknya separuh dari semua anak pernah mengalami satu kali fraktur selama masa kanak-kanak. ${ }^{3}$ Hal ini erat kaitannya dengan anatomi tulang pada anak yang berbeda dengan dewasa. Tulang pada anak memiliki kandungan air yang lebih tinggi serta kandungan mineral yang rendah per satuan volume dibandingkan dengan tulang dewasa. Oleh karena itu, tulang anak- anak memiliki modulus elastisitas yang lebih rendah atau mudah rapuh.3,4

Prevalensi fraktur pada anak laki-laki lebih tinggi dibanding pada anak perempuan, yaitu 2,7:1. Insiden fraktur pada anak laki-laki tercatat 450 per 10.000 kasus per tahun dengan insiden puncak pada usia 16 tahun. Sementara itu, pada anak perempuan puncaknya adalah pada usia 12 tahun dengan insiden 250 per 10.000 kasus per tahun. ${ }^{3}$ Hasil ini sama dengan penelitian di salah satu rumah sakit Indonesia. Penelitian tersebut menunjukkan kejadian fraktur cukup banyak yaitu 161 kasus antara Januari-Desember 2015. Dari seluruh kasus fraktur anak tersebut 79,5 \% berjenis kelamin laki-laki dan 20,5\% berjenis kelamin perempuan. Hal ini terjadi kemungkinan dikarenakan oleh pengaruh fisiologis hormon yang mengakibatkan anak laki-laki umumnya lebih berjiwa berpetualang dan akan lebih cenderung berpartisipasi dalam kegiatan fisik yang berisiko untuk terjadinya fraktur. ${ }^{5}$
Jenis fraktur yang tersering pada anak-anak adalah fraktur tertutup dibandingkan fraktur terbuka yang hanya $<5 \%$ dari seluruh kejadian fraktur pada anak. ${ }^{3}$ Menurut salah satu penelitian di Indonesia fraktur tunggal menjadi fraktur tersering pada anak, diikuti fraktur majemuk, fraktur greenstick, epiphyolisis, sementara yang jarang terjadi adalah fraktur kominutif. Fraktur tunggal pada anak pada umumnya disebabkan oleh kecelakaan lalu lintas di jalan dan mayoritas melibatkan ekstremitas atas. Oleh karena itu, perlunya perhatian yang lebih terhadap keselamatan lalu lintas di Indonesia. ${ }^{5}$

Penyebab fraktur pada anak dapat terjadi karena trauma tunggal seperti kecelakaan, tekanan berulang misalnya karena menari atau olahraga, ataupun karena keadaan patologis seperti tumor yang menyebabkan fraktur patologik. ${ }^{1}$ Dari data yang ada menunjukkan kecelakaan lalu lintas merupakan penyebab tersering dengan persentase $50,7 \%$ dan jatuh dibawah 1 meter menempati urutan kedua setelahnya yaitu sebanyak $34 \%$ sedangkan untuk jatuh diatas 1 meter dan trauma tumpul sangat jarang terjadi sehingga didapatkan persentasenya masing-masing hanya $8 \%$ dan $6 \% .5$

Selain karena kecelakaan lalu lintas penyebab fraktur terbanyak bisa disebabkan oleh jatuh. Penelitian di Georgia didapatkan terdapat 1086 anak-anak usia 0-4 tahun yang mengalami cedera akibat jatuh. Dari penelitian tersebut didapatkan fraktur humerus menempati urutan pertama dengan persentasi $27 \%$ dari seluruh cedera akibat jatuh, diikuti fraktur tengkorak dan fraktur femur diurutan kedua dan ketiga. ${ }^{6}$ Hal ini dikarenakan perubahan struktur anatomi tubuh anak-anak seperti perubahan struktur kepala yang semakin kecil dan kekuatan ekstremitas atas yang semakin bertambah seiring bertambahnya usia.6,7 Pada bayi proporsi massa kepala lebih besar dibanding tubuh sehingga lebih cenderung mengalami cedera kepala sedangkan balita memiliki proporsi massa kepala yang lebih kecil dari pada tubuh dan memiliki ektremitas yang lebih kuat. Oleh sebab itu, balita cenderung menggunakan ekstremitas atas untuk menopang tubuhnya sehingga mengakibatkan fraktur pada humerus. $6,7,8$

Fraktur humerus pada anak yang tersering adalah fraktur suprakondiler. Angka kejadian pada anak sekitar $55 \%$ sampai $75 \%$ dari semua 
fraktur siku dan insiden puncak terjadi saat usia 5-8 tahun. Fraktur suprakondiler tipe ekstensi lebih sering terjadi dibandingkan tipe fleksi dengan persentasi $98 \%$ dari semua kasus fraktur suprakondiler pada anak. ${ }^{3}$ Hal ini terjadi karena kelemahan ligament yang bersifat fisiologi sehingga kemampuan hiperekstensi sendi siku umum terjadi pada masa kanak-kanak. Kemudian kolum bagian medial dan lateral dari humerus distal dihubungkan oleh segmen tipis dari tulang antara olekranon pada bagian posterior dan koronoid pada fossa anterior, yang menyebabkan tingginya risiko terjadinya fraktur pada daerah tersebut. ${ }^{9,10}$

Penatalaksanaan fraktur humerus pada anak dibagi menjadi dua, yaitu secara konservatif (nonoperatif) dan operatif. Beberapa hasil penelitian menyatakan bahwa terapi dengan operatif menghasilkan hasil akhir yang lebih baik dibandingkan non operatif dikarenakan metode operatif secara signifikan mengurangi kejadian baik non-union maupun malunion.11 Meskipun pengobatan modern sudah semakin berkembang, namun sebagian masyarakat masih menggunakan pengobatan tradisional. Hal ini di dukung oleh penelitian yang menyatakan bahwa $85 \%$ pasien fraktur di nigeria memilih datang pertama kali ke pengobatan traditional dikarenakan kebudayaan dan kepercayaan mereka. ${ }^{12}$ Penelitian lain juga menemukan bahwa pasien fraktur yang berobat ke pengobatan tradisional di barat-daya nigeria mengalami komplikasi gangrene. Komplikasi ini selanjutnya dapat menjadi indikasi dilakukannya amputasi pada anak- anak. ${ }^{13}$

Penelitian mengenai fraktur humerus masih sangat kurang, khususnya di daerah Sumatera Barat. Oleh karena itu, peneliti ingin melihat distribusi fraktur humerus pada anak yang di rawat di RSUP dr. M. Djamil Padang pada tahun 2014-2017. Penelitian ini diharapkan dapat membantu memfokuskan prediksi kejadian fraktur humerus dengan memberi pemahaman mendalam tentang orang-orang yang memiliki faktor risiko tinggi mengalami fraktur, serta memberikan informasi tentang karakteristik fraktur humerus di RSUP dr. M. Djamil Padang pada tahun 2014-2017.

\section{Metode}

Penelitian ini telah dilaksanakan di Bagian Rekam Medik RSUP dr. M. Djamil Padang pada bulan April 2018 sampai bulan Desember 2018. Penelitian ini bersifat deskriptif menggunakan data sekunder pasien yang dirawat di Poli Bedah Orthopedi dari tahun 2014- 2017 yang memenuhi kriteri inklusi yaitu jenis kelamin, usia, lokasi fraktur, jenis fraktur, tatalaksana dan faktor penyebab fraktur humerus. Data diolah secara manual menggunakan microsoft excel 2013 dan disajikan dalam bentuk tabel distribusi frekuensi.

\section{Hasil}

Penelitian ini dilakukan pada 43 orang pasien dengan fraktur humerus berusia dibawah 18 tahun yang dirawat di RSUP dr. M. Djamil Padang sejak tahun 2014 sampai tahun 2017. Penelitian ini dilakukan di Instalasi Rekam Medik RSUP dr. M. Djamil Padang. Tujuan penelitian ini adalah untuk mengevaluasi epidemiologi fraktur humerus pada anak yang dirawat di RSUP dr. M. Djamil Padang.

\section{Frekuensi Fraktur Humerus}

Tabel 1. Frekuensi Fraktur Humerus

\begin{tabular}{ccc}
\hline Tahun & Frekuensi & Persentase (\%) \\
\hline 2014 & 13 & $30,3 \%$ \\
2015 & 5 & $11,6 \%$ \\
2016 & 16 & $37,2 \%$ \\
2017 & 9 & $20,9 \%$ \\
\hline Total & $\mathbf{4 3}$ & $\mathbf{1 0 0} \%$ \\
\hline
\end{tabular}

Frekuensi fraktur humerus dari penelitian ini didapatkan 43 pasien yang memenuhi kriteria inklusi dan kriteria ekslusi untuk dijadikan sampel penelitian ini. Berdasarkan tabel 1 diperoleh data bahwa frekuensi fraktur humerus pernah mengalami penurunan pada tahun 2015 $(11,6 \%)$ namun meningkat secara signifikan pada tahun 2016 (37,2\%).

\section{Distribusi Frekuensi Kejadian Fraktur Humerus Berdasarkan Jenis Kelamin dan Usia}

Tabel 2. Distribusi Fraktur Humerus Berdasarkan Jenis Kelamin dan Usia

\begin{tabular}{lcc}
\hline \multicolumn{1}{r}{ Variabel } & Frekuensi & Persentase (\%) \\
\hline Jenis Kelamin & & \\
Laki-laki & 32 & $74,4 \%$ \\
Perempuan & 11 & $25,6 \%$ \\
Usia (tahun) & & \\
$0-1$ & 1 & $2,3 \%$ \\
$2-4$ & 3 & $7 \%$ \\
$5-11$ & 18 & $41,9 \%$ \\
$12-17$ & 21 & $48,9 \%$ \\
\hline \multicolumn{1}{c}{ Total } & $\mathbf{4 3}$ & $\mathbf{1 0 0 \%}$ \\
\hline
\end{tabular}


Berdasarkan tabel 2 diperoleh data bahwa sampel yang berjenis kelamin laki-laki lebih banyak dibandingkan sampel yang berjenis kelamin wanita dengan persentase 2,9:1.

Berdasarkan tabel 2 juga, diperoleh data bahwa kelompok usia 12-17 tahun (48,9\%) berisiko tinggi terkena fraktur. Sedangkan kelompok usia 0-1 tahun (2,3\%) merupakan kelompok usia yang memiliki risiko rendah terkena fraktur.

\section{Distribusi Frekuensi Kejadian Fraktur Humerus Berdasarkan Lokasi Fraktur Humerus dan Jenis Fraktur}

Tabel 3. Distribusi Fraktur Humerus Berdasarkan Lokasi Fraktur Humerus dan Jenis Fraktur

\begin{tabular}{lcc}
\hline \multicolumn{1}{c}{ Variabel } & Frekuensi & Persentase (\%) \\
\hline Lokasi Fraktur & & \\
Proksimal & 4 & $9,3 \%$ \\
Batang & 9 & $20,9 \%$ \\
Distal & 30 & $69,8 \%$ \\
Suprakondiler & 20 & $46,5 \%$ \\
Lateral Kondiler & 6 & $14 \%$ \\
Medial Kondiler & 4 & $9,3 \%$ \\
Jenis Fraktur & & \\
Terbuka & 10 & $23,3 \%$ \\
Tertutup & 33 & $76,7 \%$ \\
\hline \multicolumn{1}{c}{ Total } & $\mathbf{4 3}$ & $\mathbf{1 0 0} \%$ \\
\hline
\end{tabular}

Berdasarkan tabel 3 diperoleh data bahwa lokasi yang paling rentan terkena fraktur humerus adalah pada bagian distal yaitu sebanyak 30 kasus (69,3\%). Sebanyak 20 kasus dari semua fraktur distal humerus terletak didaerah suprakondiler humerus. Sehingga fraktur suprakondiler merupakan fraktur humerus tersering yang dialami anak-anak pada penelitian ini dengan persentase $46,5 \%$.

Berdasarkan tabel 3 juga, diperoleh data bahwa fraktur humerus jenis tertutup (76,7\%) lebih sering ditemukan dibandingkan jenis terbuka $(23,3 \%)$.

\section{Distribusi Frekuensi Kejadian Fraktur Humerus Berdasarkan Tatalaksana}

Tabel 4. Distribusi Fraktur Humerus Berdasarkan Tatalaksana

\begin{tabular}{ccc}
\hline Tindakan & Frekuensi & Persentase (\%) \\
\hline Konservatif & 17 & $39,5 \%$ \\
Operatif & 26 & $60,5 \%$ \\
\hline Total & $\mathbf{4 3}$ & $\mathbf{1 0 0 \%}$ \\
\hline
\end{tabular}

Berdasarkan tabel 4 diperoleh data bahwa pasien anak yang mengalami fraktur humerus umumnya ditatalaksana secara operatif $(60,5 \%)$.

\section{Distribusi Frekuensi Kejadian Fraktur Humerus Berdasarkan Faktor Penyebab}

Tabel 5. Distribusi Fraktur Humerus Berdasarkan Faktor Penyebab

\begin{tabular}{lcc}
\hline \multicolumn{1}{c}{ Faktor Penyebab } & Frekuensi & $\begin{array}{c}\text { Persentase } \\
\text { (\%) }\end{array}$ \\
\hline Peristiwa trauma tunggal & 43 & $100 \%$ \\
Kecelakaan lalu lintas & 29 & $67,4 \%$ \\
Terjatuh dari ketinggian & 14 & $32,6 \%$ \\
Tekanan berulang & 0 & $0 \%$ \\
$\begin{array}{l}\text { Kelemahan abnormal } \\
\text { tulang }\end{array}$ & 0 & $0 \%$ \\
\multicolumn{1}{c}{$\quad$ Total } & $\mathbf{4 3}$ & $\mathbf{1 0 0 \%}$ \\
\hline
\end{tabular}

Berdasarkan tabel 5 diperoleh data bahwa peristiwa trauma tunggal merupakan satusatunya faktor penyebab fraktur humerus pada anak dengan persentase 100\%. Kecelakaan lalu lintas merupakan penyebab tersering fraktur humerus pada anak dengan persentase $67,4 \%$ diikuti terjatuh dari ketinggian yang hanya $32,6 \%$.

\section{Pembahasan}

Penelitian ini dilakukan pada 43 orang pasien dengan fraktur humerus berusia dibawah 18 tahun yang dirawat di RSUP dr. M. Djamil Padang sejak tahun 2014 sampai tahun 2017. Penelitian ini dilakukan di Instalasi Rekam Medik RSUP dr. M. Djamil Padang. Tujuan penelitian ini adalah untuk mengevaluasi epidemiologi fraktur humerus pada anak yang dirawat di RSUP dr. M. Djamil Padang.

\section{Frekuensi Fraktur Humerus}

Berdasarkan tabel 1 diperoleh data bahwa frekuensi fraktur humerus pernah mengalami penurunan pada tahun 2015 (11,6\%) namun meningkat secara signifikan pada tahun 2016 $(37,2 \%)$ dan akhirnya mengalami penurunan kembali pada tahun 2017 (20,9\%). Hasil ini menunjukkan bahwa kejadian fraktur humerus pada anak setiap tahunnya mengalami fluktuatif. Hal ini diduga berkaitan dengan kecelakaan lalu lintas yang merupakan penyebab fraktur tersering yang ditemukan pada penelitian ini dengan persentasi $67,4 \%$ dari seluruh penyebab fraktur.

Data dari Badan Pusat Statistika menunjukkan bahwa angka kecelakaan lalu lintas di Indonesia mengalami fluktuatif setiap tahunnya. Pada tahun 2015 tercatat ada 98.970 kasus kecelakan di Indonesia dan meningkat pada tahun 2016 
sebanyak 106.129 kasus dan akhirnya menurun kembali menjadi 98.419 pada tahun 2017.14,15

\section{Distribusi Frekuensi Kejadian Fraktur Humerus Berdasarkan Jenis Kelamin}

Distribusi frekuensi kejadian fraktur humerus berdasarkan jenis kelamin didapatkan bahwa laki-laki lebih banyak dibandingkan perempuan. Berdasarkan tabel 2 jenis kelamin pasien fraktur humerus didominasi laki-laki yaitu sebanyak 32 orang $(74,4 \%)$, sedangkan perempuan hanya 11 orang $(25,6 \%)$. Hal ini menunjukkan bahwa perbandingan antara laki-laki dan perempuan pada penelitian ini adalah 2,9:1. Hasil ini tidak jauh berbeda dengan penelitian terhadap 161 kasus fraktur pada anak disalah satu rumah sakit di Indonesia yang terjadi yang menunjukkan bahwa ratio laki-laki dan perempuan adalah $3,9: 1 .^{5}$

Perbedaan yang sangat signifikan antara angka kejadian fraktur antara laki-laki dan perempuan terjadi kemungkinan dikarenakan oleh pengaruh fisiologis hormon yang mengakibatkan anak laki-laki umumnya lebih berjiwa berpetualang dan akan lebih cenderung berpartisipasi dalam kegiatan fisik yang berisiko untuk terjadinya fraktur. ${ }^{5}$

\section{Distribusi Frekuensi Kejadian Fraktur humerus Berdasarkan Usia}

Distribusi frekuensi kejadian fraktur humerus berdasarkan kelompok usia didapatkan hasil bahwa kelompok usia tersering terkena fraktur humerus adalah kelompok masa remaja yaitu usia 12-17 tahun sebanyak 21 orang (48,9\%). Hal ini sesuai dengan penelitian disalah satu rumah sakit di Indonesia yang mendapatkan bahwa kelompok usia tersering adalalah usia 1217 tahun yang berjumlah 74 orang (46\%), diikuti kelompok usia 5-11 tahun sebanyak 48 orang $(29,8 \%)$ dan kedua terakhir yaitu usia $0-1$ tahun $(12,4 \%)$ dan usia $2-4$ tahun $(11,8 \%) .5$ Menurut penelitian lain menunjukkan bahwa usia 10-14 tahun memiliki resiko tinggi terkena fraktur. ${ }^{16}$

Berdasarkan hasil penelitian diatas jika dihubungkan dengan hasil penelitian ini maka dapat disimpulkan bahwa fraktur humerus pada anak khususnya di Indonesia paling sering mengenai kelompok usia remaja. Hal ini terjadi dikarenakan perubahan pola aktivitas akibat perkembangan keterampilan sosial dan motorik seiring bertambahnya usia sehingga meningkatkan resiko fraktur pada anak. ${ }^{17}$

\section{Distribusi Frekuensi Kejadian Fraktur Humerus Berdasarkan Lokasi Fraktur Humerus}

Distribusi frekuensi kejadian fraktur humerus berdasarkan lokasi fraktur humerus didapatkan bahwa lokasi distal humerus merupakan salah satu bagian dari humerus yang mempunyai resiko tertinggi terkena fraktur. Berdasarkan tabel 4 didapatkan bahwa distal humerus merupakan lokasi tersering terkena fraktur yaitu sebanyak 69,3\%. Hal ini sesuai dengan penelitian yang meneliti epidemiologi fraktur humerus di Amerika Serikat. Pada penelitian tersebut ditemukan bahwa fraktur humerus tersering pada usia anak adalah fraktur distal humerus sedangkan fraktur proksimal humerus jarang mengenai anak-anak, namun sering dijumpai pada usia dewasa dengan puncak usia $>80$ tahun dan fraktur batang humerus memiliki frekuensi yang hampir sama pada semua kelompok usia. ${ }^{18}$

Pada penelitian ini juga didapatkan bahwa dari berbagai jenis fraktur distal humerus yang terbanyak adalah di daerah suprakondiler yang merupakan daerah tersering terkena fraktur. Hasil ini sesuai dengan penelitian yang mendapatkan bahwa fraktur suprakondiler humerus merupakan fraktur tersering dengan persentasi $60 \%$ dari semua fraktur siku dan 16 $\%$ dari seluruh fraktur yang terjadi pada anak. ${ }^{19}$

Jadi, dapat disimpulkan bahwa fraktur humerus tersering pada anak yaitu fraktur distal humerus. Hal ini terjadi dikarenakan mekanisme cedera, biasanya apabila anak-anak terjatuh, cenderung posisi siku tangan yang akan menopang tubuh sehingga mengakibatkan fraktur pada daerah distal lebih sering terjadi dibandingkan bagian lainnya. ${ }^{3,20}$

Penelitian lebih spesifik menunjukkan bahwa fraktur bagian suprakondiler merupakan fraktur tersering didaerah distal humerus. Hal ini terjadi karena kelemahan ligamen yang bersifat fisiologi sehingga kemampuan hiperekstensi sendi siku umum terjadi pada masa kanak-kanak. Kemudian kolum bagian medial dan lateral dari humerus distal dihubungkan oleh segmen tipis dari tulang antara olekranon pada bagian 
posterior dan koronoid pada fossa anterior, yang menyebabkan tingginya risiko terjadinya fraktur pada daerah suprakondiler tersebut. 9,10

\section{Distribusi Frekuensi Kejadian Fraktur Humerus Berdasarkan Jenis Fraktur Humerus}

Distribusi frekuensi kejadian fraktur humerus berdasarkan jenis fraktur humerus didapatkan bahwa fraktur tertutup lebih sering dibanding fraktur terbuka. Berdasarkan tabel 5 didapatkan perbandingan antara fraktur tertutup dan terbuka 3,3:1. Hal ini sesuai dengan penelitian terhadap kasus fraktur humerus dan didapatkan bahwa jumlah pasien fraktur tertutup 66 pasien dimana hal ini lebih banyak dibanding fraktur terbuka yang hanya 30 pasien. ${ }^{21}$ Penelitian lain yang juga mendukung hasil penelitian ini didapatkan juga jenis fraktur suprakondiler humerus tersering adalah jenis tertutup dan hanya sebagian kecil merupakan fraktur terbuka. ${ }^{22}$

Jadi, dari beberapa penelitian diatas menunjukkan bahwa jenis fraktur tersering pada anak adalah fraktur tertutup, hal ini diduga dipengaruhi oleh beban aktivitas anak yang tidak terlalu berat dibandingkan dewasa, sehingga tingkat keparahan fraktur relatif lebih ringan berupa fraktur tertutup..$^{21}$

\section{Distribusi Frekuensi Kejadian Fraktur Humerus Berdasarkan Tatalaksana}

Distribusi frekuensi kejadian fraktur humerus berdasarkan tatalaksana, didapatkan bahwa pengobatan secara operatif lebih sering dilakukan pada pasien fraktur dengan persentasi $60,5 \%$. Dari hasil penelitian menyatakan bahwa terapi dengan operatif menghasilkan hasil akhir yang lebih baik dibandingkan non operatif. Hal ini dikarenakan penatalaksanaan dengan metode operatif secara signifikan mengurangi kejadian baik non-union maupun malunion. ${ }^{11}$ Hasil ini juga sesuai dengan penelitian terhadap pasien fraktur humerus di salah satu rumah sakit di Jember dan didapatkan bahwa terdapat komplikasi angulasi yang cukup besar pada pasien fraktur humerus yang ditatalaksana dengan terapi konservatif. ${ }^{23}$

Meskipun penelitian-penelitian diatas menyebutkan bahwa tindakan operatif lebih baik dibandingkan kuratif, namun tidak bisa dipungkiri kalau tatalaksana konservatif merupakan pilihan pertama untuk tatalaksana fraktur pada anak. Hal ini sesuai dengan penelitian yang menyatakan bahwa terapi konservatif merupakan pilihan utama pada kasus fraktur anak dikarenakan tulang anak masih memiliki periosteum yang lebih aktif dan kemampuan remodeling yang baik. ${ }^{24}$

Pada penelitian ini peneliti menganalisa bahwa masih banyak terjadi keterlambatan penanganan fraktur yang disebabkan oleh kurangnya pengetahuan dan kesadaran masyarakat untuk memeriksa anaknya ketenaga kesehatan apabila mengalami tanda dan gejala fraktur. Mereka cenderung pergi ke pengobatan tradisional, namun ketika sudah beberapa bulan fraktur tidak kunjung sembuh dan mengalami komplikasi, barulah mereka kemudian membawanya ke tenaga kesehatan. Hal inilah yang menyebabkan tatalaksana kuratif sudah tidak bisa lagi diberikan pada kasus lama dikarenakan komplikasi berat yang ditimbulkan. Oleh sebab itu, tatalaksana operatif menjadi pilihan utama untuk mengatasi fraktur pada anak. ${ }^{11}$

Berdasarkan penelitian-penelitian diatas, dapat disimpulkan bahwa tidak semua fraktur pada anak dapat ditangani dengan terapi konservatif. Beberapa penelitian telah menunjukkan bahwa fraktur humerus pada anakanak memiliki hasil yang lebih baik bila ditangani secara operatif mengingat sedikitnya komplikasi yang ditimbulkan. ${ }^{23}$

\section{Distribusi Frekuensi Kejadian Fraktur Humerus Berdasarkan Faktor Penyebab}

Karakteristik sampel penelitian berdasarkan faktor penyebabnya, didapatkan hasil bahwa trauma tunggal merupakan satu-satunya faktor penyebab terjadinya fraktur humerus pada anak. Kecelakaan lalu lintas merupakan penyebab tersering disusul terjatuh dari ketinggian seperti, jatuh dari pohon ataupun tempat bermain. Hal ini sesuai dengan penelitian yang menemukan bahwa fraktur tunggal pada anak pada umumnya disebabkan oleh kecelakaan lalu lintas di jalan dan mayoritas melibatkan ekstremitas atas. Dari data yang ada menunjukkan kecelakaan lalu lintas merupakan penyebab tersering dengan persentase 50,7\% dan jatuh dibawah 1 meter menempati urutan kedua setelahnya yaitu sebanyak $34 \quad \%$ 
sedangkan untuk jatuh diatas 1 meter dan trauma tumpul sangat jarang terjadi sehingga didapatkan persentasenya masing-masing hanya $8 \%$ dan $6 \% .^{5}$

Penelitian lain juga menunjukkan bahwa trauma tunggal merupakan penyebab utama fraktur pada anak. Penelitian terhadap 118 kasus fraktur suprakondiler didapatkan bahwa mayoritas penyebab fraktur pada anak adalah karena jatuh dari arena bermain serta 115 kasus merupakan usia sekolah. 25

Oleh sebab itu, perlunya perhatian yang lebih terhadap keselamatan lalu lintas di Indonesia serta keselamatan anak di arena bermain agar kejadian fraktur humerus dapat di tekan atau bahkan dapat diturunkan. ${ }^{5}$

\section{Simpulan}

Berdasarkan hasil penelitian yang telah dilakukan terhadap fraktur humerus pada pasien anak yang dirawat di Bagian Bedah Orthopedi RSUP dr. M. Djamil Padang pada tahun 2014-2017 didapatkan kesimpulan bahwa frekuensi fraktur humerus mengalami penurunan pada tahun 2015 namun meningkat secara signifikan pada tahun 2016.

Mayoritas fraktur humerus pada anak-anak terjadi pada jenis kelamin laki-laki yaitu pada kelompok usia 12-17 tahun. Lokasi fraktur humerus tersering yaitu pada bagian distal terutama pada bagian suprakondiler. Jenis fraktur yang terbanyak adalah fraktur tertutup dan tindakan operatif lebih banyak dilakukan untuk kasus fraktur humerus. Fraktur humerus umumnya terjadi karena trauma tunggal baik itu kecelakaan lalu lintas, terjatuh dari ketinggian seperti, saat sedang bermain di arena permainan atau saat memanjat pohon.

\section{Ucapan Terima Kasih}

Terimakasih kepada semua pihak atas bimbingan, arahan dan motivasi yang diberikan pada penelitian ini.

\section{Daftar Pustaka}

1. Solomon L. Apley's System of Orthopedics and Fractures. Ed.9. London : Hachette UK;2010.hlm.687732.

2. Noor Z. Buku ajar gangguan muskuloskeletal. Ed.2. Jakarta: Salemba Medika; 2016.hlm.478-82.

3. Egol KA, Koval KJ, Zuckerman JD. Handbook Of Fractures. Ed.5. Philadelphia: Lippincott Williams \& Wilkins; 2015.hlm.497-8.
4. Luqmani R, James R. Textbook of Orthopedics, Trauma, and Rheumatology. London: Elsevier; 2013.hlm.132-141.

5. Nugraha HK, Adiantono A. Epidemiology of fractures and dislocations in children. Folia Medica Indonesiana. 2017. 53 (1): 81-5.

6. Caundary S. Pediatric falls ages 0-4: understanding demographics, mechanisms, and injury severities. Inj Epidemiol. 2018. 5(Suppl 1): 7.

7. Kamboj A, Chounthirath T, Xiang H, Smith G. Traumatic brain injuries associated with consumer products at home among US children younger than 5 years of age. Clin Pediatr. 2017; 56(6): 545-54.

8. Wang D, Zhao W, Wheeler K, Yang G, Xiang H. Unintentional fall injuries among US children: a study based on the National Emergency Department Sample. Int J Inj Control Saf Promot. 2013; 20: 27-35.

9. Beaty JH, Kasser JR. Supracondylar fractures of the distal humerus. Rockwood and Wilkins' fractures in children. Ed.5. Philadelphia: Lippincott Williams and Wilkins; 2005.hlm.614-20.

10. Kulkarni GS. Textbook of orthopedics and trauma. Ed.3. New Delhi: Jaype Brothers Medical Publisher; 2016. pp. 2907-22.

11. Hayashi A. Surgical treatment may be more effective for humeral fractures. American Association of Orthopedic Surgeons. 2009. https://www.aaos.org/AAOSNow/2009/Dec/clinic al/clinical3/?ssopc=1 - Diakses 1 Mei 2018.

12. Omololu AB, Ogunlade SO, Gopaldsani VR. The practice of Traditional Bonesetting: Training algorithm. Clin. Orthop. Relat. Res.2008; 466:2392-8.

13. Ogunlusi JD, Okem IC, Oginni LM. Why patients patronize traditional bonesetters. Internet J Orthop Surg.2007; 4(2):1-7.

14. Badan Pusat Statistika. Jumlah Kecelakan, Korban Mati, Luka Berat, Luka Ringan, dan Kerugian Materi yang Diderita Tahun 1992-2016. 2017. https://www.bps.go.id/linkTableDinamis/view/id/1 134 - Diakses 30 November 2018.

15. Badan Pusat Statistika. Statistik Transportasi Darat 2017. Jakarta: BPS RI; 2018. hlm. 38.

16. Naranje SM, Erali RA, Warner WC, Sawyer JR, Kelly DM. Epidemiology of Pediatric Fractures Presenting to Emergency Departments in the United States. J Pediatr Orthop. 2016; 36(4): e45- 8.

17. Hedström EM, Svensson O, Bergström U, Michno P. Epidemiology of fractures in children and adolescents. Acta Orthop. 2010; 81 (1): 148-153.

18. Kim SH, Szabo RM, Marder RA. Epidemiology of humerus fractures in the United States: nationwide emergency department sample, 2008. Arthritis Care \& Research. 2012; 64(3): 407-14.

19. Kumar V, Ajai S. Fracture Supracondylar Humerus: A Review. J Clin Diagn Res. 2016; 10(12): RE01-6.

20. Thompson JC. Netter's: Concise Orthopedic Anatomy 2nd ed. Philadelphia: Elsevier Inc; 2010. pp. 109-16.

21. Lewine E, Kim JM, Miller PE, Waters PM, Mahan ST, Snyder B, et al. Closed Versus Open Supracondylar Fractures of the Humerus in Children: A Comparison of Clinical and Radiographic Presentation and Results. J Pediatr Orthop. 2018; Feb; 38(2): 77-81.

22. Holt JB, Glass NA, Shah AS. Understanding the Epidemiology of Pediatric Supracondylar Humeral Fractures in the United States. J Pediatr Orthop.2018; 38(5): e245-51.

23. Djaya AM, Hasan M, Efendi E. Perbandingan Komplikasi Malunion pada Pasien Fraktur Humerus 
Pasca Terapi Operatif dan Non-Operatif di RS Bina Sehat. E-Jurnal Pustaka Kesehatan.2014; 2 (1):1-3.

24. Wilkins KE. Principles of fracture remodeling in children. Injury.2005; 36(1): S3-11.

25. Barr LV. Pediatric Supracondylar Humeral Fractures: Epidemiology, Mechanisms, and incidence during school holidays. J Child Orthop. 2014; 8:167-70. 